\title{
Implementation of a chest drain bundle at Stepping Hill Hospital has improved the quality of chest drain insertion and patient safety
}

\author{
Authors: Diana Tanase, ${ }^{\mathrm{A}}$ Pauline Holmes, ${ }^{\mathrm{A}}$ Neela Surange, ${ }^{\mathrm{A}}$ Dan Tanase ${ }^{\mathrm{A}}$ and Vandana Gupta ${ }^{\mathrm{A}}$
}

\section{Background}

Intercostal chest drains are required in a number of clinical settings. Despite the move towards Seldinger chest drains, concerns have remained about patient safety and the number of serious complications seen. ${ }^{1}$ The British Thoracic Society released guidance in 2010 relating to chest drain insertion and management. ${ }^{2}$ Chest-drain-related incidents are under-reported, so we undertook a project to monitor the quality of our chest drain insertion and whether the introduction of a bundle could improve outcomes.

\section{Aim}

To investigate the effect of introducing a trust-wide chest drain bundle on the quality of chest drain insertion and patient safety.

\section{Method}

We performed a retrospective study of case notes on all patients admitted requiring an intercostal chest drain between March 2016 and March 2017; we gathered information about whether patients gave consent, ultrasound usage in effusions, documentation of the procedure and overall complications. The chest drain bundle, consisting of a quick view chest drain insertion guide and procedure proforma, written consent form, observation chart, and patient information leaflet, was then launched in August 2018. Simultaneously, a new chest drain standard operating procedure (SOP) was released and multiple educational training sessions for all members of the clinical team were held around the Trust. Using the plan, do, study, act (PDSA) principles we then re-evaluated patients requiring chest drains following implementation of the bundle and SOP (September 2018 to March 2019).

\section{Results}

50 patients (mean age 68.2 ; male $62 \%$; female $38 \%$ ) were identified pre-implementation of the bundle and 41 postintervention (mean age 64.7; male 50\%; female $50 \%$ ).

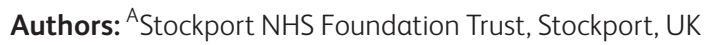

\begin{tabular}{lll}
\hline Table 1. Chest drain bundle results & \\
\hline & $\begin{array}{l}\text { Pre bundle } \\
\text { implementation } \\
\text { ( } \mathrm{n}=50, \% \text { patients) }\end{array}$ & $\begin{array}{l}\text { Post bundle } \\
\text { implementation } \\
\text { ( } \mathrm{n}=41, \% \text { patients) }\end{array}$ \\
$\begin{array}{l}\text { Written consent } \\
\text { (non-emergency) }\end{array}$ & 52.6 & 80 \\
$\begin{array}{l}\text { Bedside ultrasound } \\
\text { (effusions) }\end{array}$ & 80 & 96 \\
$\begin{array}{l}\text { Documentation } \\
\text { (site, asepsis, size, } \\
\text { type) }\end{array}$ & 74 & 94 \\
$\begin{array}{l}\text { Escalation to } \\
\text { doctor if drain not } \\
\text { functioning }\end{array}$ & 62 & 87.8 \\
$\begin{array}{l}\text { Patients } \\
\text { experiencing pain } \\
\text { Overall } \\
\text { complications }\end{array}$ & 26 & 9.7 \\
\hline
\end{tabular}

Implementing a chest drain bundle increased written consent in non-emergency situations from $52.6 \%$ to $80.0 \%$ and the use and documentation of bedside ultrasound in effusions from $80 \%$ to $96 \%$.

Overall documentation of the procedure improved from $74.0 \%$ to $94.0 \%$ (site of insertion, asepsis, type and size of drain). Although drain chart records were equally well kept prior to and after bundle implementation (92\%), escalation to doctors if drains were not working greatly improved following the bundle ( $62 \%$ vs $87.8 \%$ ).

$26 \%$ of patients experienced pain before bundle implementation and $9.7 \%$ after, and overall complications reduced from $26 \%$ preto $20 \%$ post-bundle.

\section{Conclusion}

Introduction of a chest drain bundle has shown to be a simple yet effective way of improving our practice of chest drain insertion and reducing complications at our DGH. The bundle could be 
developed for use in other trusts around the UK. We plan to continue the PDSA cycle with further educational sessions aimed at medical and nursing staff across the Trust. A further evaluation is planned to ensure we are seeing consistent improvement.

\section{Conflicts of interest}

None declared.

\section{References}

1 National Patient Safety Agency. Rapid response report: risks of chest drain insertion. NPSA, 2008. www.npsa.nhs.uk/nrls/alerts-anddirectives/rapidrr/risks-of-chest-drain-insertion

2 Havelock T, Teoh R, Laws D et al. Pleural procedures and thoracic ultrasound: British Thoracic Society pleural disease guideline 2010. Thorax 2010;65(Suppl 2):ii61-76. 